TAO, Vol. 13, No. 2, 109-124, June 2002

\title{
Thermo-tectonic Implications of Zircon and Apatite FT Data of the Marlborough Region, South Island, New Zealand
}

\author{
Ming-Hung Kao ${ }^{1, *}$ \\ (Manuscript received 8 March 2001, in final form 28 March 2002)
}

\begin{abstract}
Zircon and apatite fission track (FT) reveal some of the thermo-tectonic features of the Marlborough Region, South Island, New Zealand. The very young FT ages ( $<10 \mathrm{Ma}$ ) of zircon and apatite in the vicinity of the Alpine Fault bend and Seaward Kaikoura Range coincide with the recent rapid uplift/erosion. Four samples with reset zircon ages in the Alpine Fault bend reveal that the host rocks in this area cooled below the closure temperature of zircon $\left(240^{\circ} \mathrm{C}\right)$ in the late Miocene. Unlike these four zircon FT ages, most zircon FT ages are consistent with depositional ages. Annealed apatite and unannealed zircon FT ages show that the host rocks in Marlborough did not experience exposure to the closure temperature of zircon in the Mesozoic burial, but passed through the partial annealing zone (PAZ) of apatite $\left(\sim 60-110^{\circ} \mathrm{C}\right)$. The host rocks in the north rather than those in the south passed through the lower part of apatite PAZ. In addition, most of the zircon samples with low $P\left(\chi^{2}\right)$ values $(<5 \%)$ show that the samples have been slightly annealed, implying that the host rocks might have experienced the upper part of the partial annealing zone of zircon $\left(\sim 175^{\circ} \mathrm{C}\right)$ during the Mesozoic cooling.
\end{abstract}

(Key words: FT analysis, Tectonics, Closure temperature)

\section{INTRODUCTION}

Fission track (FT) analysis is a useful method for establishing low-temperature thermal histories of rock successions (Naeser 1979; Laslett et al. 1987; Green et al. 1989a, b; Rohrman et al. 1994; Kao 2001).

FT data provide information about the tectonic and thermal history of host rocks. The age and cooling of host rocks may be constrained by FT analysis. FTs in U-bearing minerals such as zircon and apatite result from the spontaneous fission of ${ }^{238} \mathrm{U}$, and can be applied to thermotectonic studies. Annealing of FTs is an important feature of FT analysis. If FT ages of host

\footnotetext{
${ }^{1}$ Institute of Earth Sciences, Academia Sinica, Taipei, Taiwan, ROC

* Corresponding author address: Dr. Ming-Hung Kao, Institute of Earth Sciences, Academia Sinica, P.O. Box 1-55, Nankang, Taipei, Taiwan, ROC; E-mail: mhkao@earth.sinica.edu.tw
} 
rocks were consistent with depositional ages, the distributions of single-grain FT ages would have higher $\mathrm{P}\left(\chi^{2}\right)$ values ( $\left.>5 \%\right)$, indicating that the host rocks had not experienced the partial annealing zone (PAZ) of zircon $\left(175^{\circ} \mathrm{C} \sim 245^{\circ} \mathrm{C}\right)$ or of apatite $\left(60^{\circ} \mathrm{C} \sim 110^{\circ} \mathrm{C}\right)$. For the annealed FT samples, the distributions of single-grain FT ages may have low $\mathrm{P}\left(\chi^{2}\right)$ values $(<5 \%)$.

"Closure temperature (CT)" is a concept that links the observed age to the temperature at which the FT age starts to accumulate (Dodson 1973; Hodges 1991). The closure temperature for zircon is about $240^{\circ} \mathrm{C}$. The closure temperature for apatite ranges from $110^{\circ} \mathrm{C}$ to $125^{\circ} \mathrm{C}$, depending on apatite composition (Gleadow and Duddy 1981; Green et al. 1989b). When the host rocks experience a higher temperature $(>\mathrm{CT})$, FTs will be totally annealed.

Although the annealing of zircon FTs is still unknown, the kinetic of annealing in apatite (Green 1986, Green et al. 1989b; Laslett et al. 1987; Duddy et al. 1988; Crowley et al. 1991) has been established and applied to thermo-tectonic studies. Thermal histories can be reconstructed from forward modeling of time-temperature histories and comparison of predicted and measured FT ages and lengths of apatite. The aim of this article is to investigate the thermo-tectonic development of basement in Marlborough by compilation of zircon data and previously reported apatite data and the modeled thermal histories of apatite (Kao 2001).

\section{GEOLOGIC SETTING}

The Marlborough region (Fig. 1) is located within the Australian-Pacific plate boundary zone at a critical position between the southem end of the Hikurangi margin and the Alpine Fault section. The Torlesse Supergroup constitutes the basement of the Marlborough region. The depositional ages of basement rocks range from the Late Jurassic to Early Cretaceous, with Triassic successions in the far west. The exposure of the Alpine Schist mainly results from Neogene denudation and partly from Cretaceous denudation (Suggate 1978b). The ages of cover strata range from Cretaceous to Quaternary (Fig. 1). When Marlborough was part of a passive margin environment, early Cenozoic sequences accumulated during a tectonically quiet period which lasted from 90 to $25 \mathrm{Ma}$ (Baker and Seward 1996). The Kaikoura Orogeny has followed the tectonic quiescence since the early Miocene, reflecting development of the modem Australia-Pacific plate boundary in the region (Browne 1995). Crustal shortening and strike-slip faulting are considered to have become increasingly important in this region since the Miocene (Carter and Norris 1976; Suggate 1978a; Baker and Seward 1996).

\section{SAMPLING AND EXPERIMENRAL PROCEDURES}

\subsection{Sampling}

The Marlborough region may be divided into four blocks by the Marlborough Fault System. They are: Wairau, Inland Kaikoura, Seaward Kaikoura, and Kahutara (Fig. 1). Eighty-eight samples (9414-1 to -88) were collected from outcrops along roads throughout Marlborough, or by helicopter from the Inland and Seaward Kaikoura Ranges. 


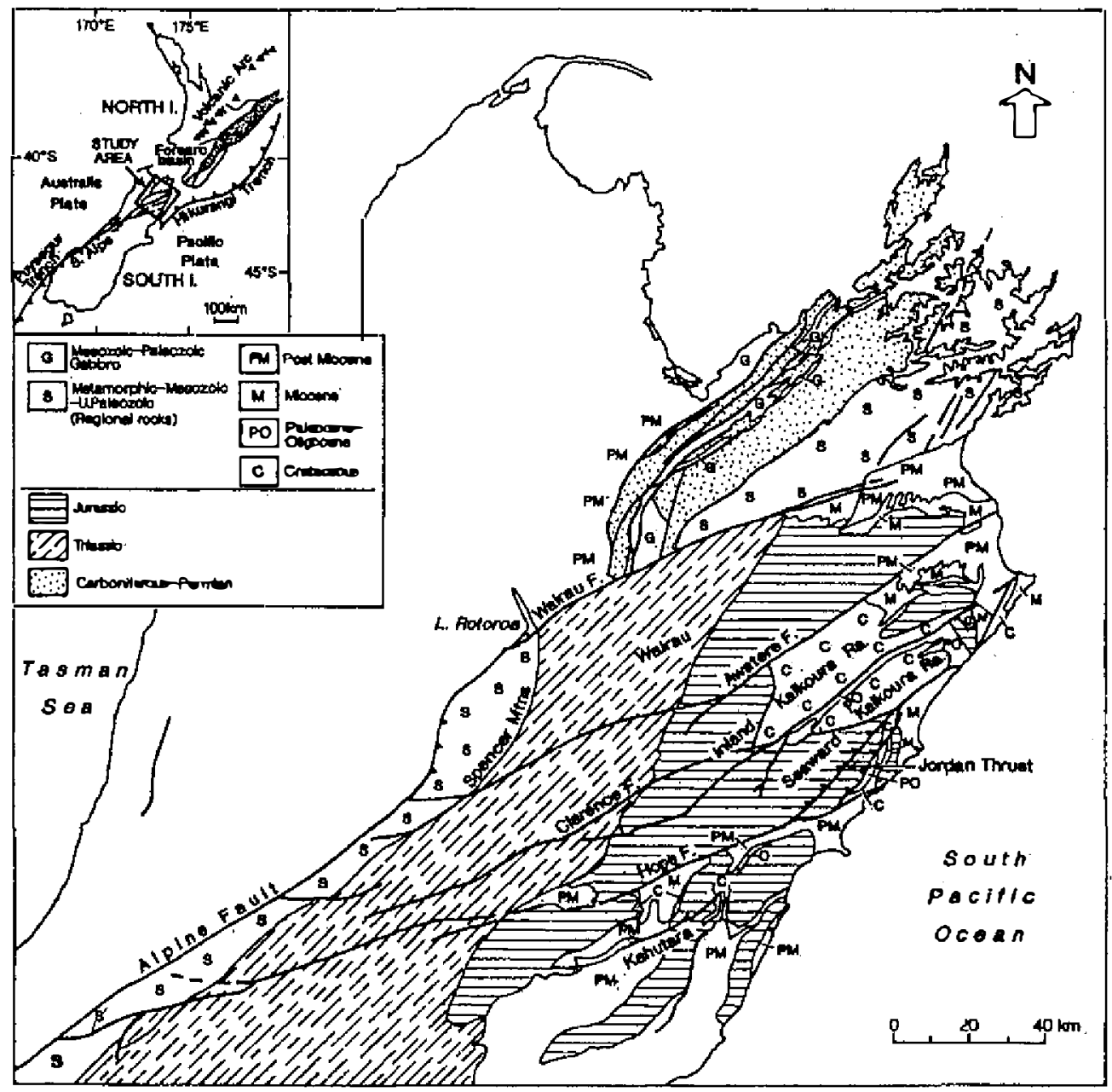

Fig. 1. Geological map of Marlborough, South Island, New Zealand (Lensen, 1962).

\subsection{Experimental Procedures}

The experiment procedures of this study were followed using the methods described in the papers of Green (1986), Kamp et al. (1989), Tippett and Kamp (1993), and Kao (1998). The separation of apatite concentrates from rock samples $(\sim 4 \mathrm{~kg})$, experimental procedures, and FT dating for apatite are stated in the paper of Kao (2001). The zircon concentrates from the same rock samples were obtained by the following methods: standard magnetic and heavy liquid techniques. Zircon concentrates were mounted in FEP Teflon ${ }^{\mathrm{TM}}$ at $\sim 300^{\circ} \mathrm{C}$ and ground to reveal internal surfaces. Once ground, zircon separates were polished with alumina slurry and then 1- $\mu \mathrm{m}$ diamond paste. The zircon mounts were etched in molten $\mathrm{KOH}-\mathrm{NaOH}$ eutectic at $\sim 205^{\circ} \mathrm{C}$. The time of etching ranged from 16 to 56 hours. Finally, zircon mounts were 
cleaned by placing them in dilute HF for 1 hour.

The experimental procedures were as follows: (a) all mounts were cut to $1 \times 1.5 \mathrm{~cm}$ and cleaned with detergent and alcohol, (b) low-uranium mica external detectors were sealed directly in contact with the mounts by using envelopes of heat-shrink plastic, (c) pinpricks were made at the corners of each mount-mica sandwich for subsequent location, (d) all mounts were stacked vertically with dosimeter glass standards ( $\mathrm{CN} 1$ for zircons) placed at the top and bottom of each stack for irradiation. Each dosimeter was also mounted with a mica detector. Afterwards, all stacks were packed into canisters and irradiated at the X-7 facility of the HIFAR reactor, New South Wales, Australia. The nominal fluence of thermal neutrons was $3 \times 10^{15}$ neutrons $\mathrm{cm}^{-2}$ for zircon.

The external detector method was applied to the FT dating (Gleadow 1981). The FT ages were determined by the zeta calibration method (Hurford and Green 1982; Green 1985). A chi-square statistic was used to assess the probability of grains counted in a sample belonging to a single population of ages (Galbraith 1981). The results of weighted mean zetas are reported in Table 1: zircon weighted mean $\zeta=140.2 \pm 3.6(\mathrm{CN} 1)$.

\section{FT RESULTS AND DISCUSSIONS}

\subsection{Zircon FT Results}

The distribution of zircon FT ages is illustrated in Fig. 2. Except for a few samples of poor zircon concentrates, zircon FT results of the Marlborough samples are shown in Table 2 and Figs. 3-6. Transects T1, T2, T3, and T4 are located within four blocks, respectively (Fig. 2). Uncertainties of FT ages are reported at the 1s level. Zircon ages of the samples range from $6.8 \pm 0.5$ to $336.2 \pm 45.3 \mathrm{Ma}$.

\subsubsection{Wairau transect (T1)}

Upper Triassic-Jurassic sandstone (greywacke) constitutes mainly the basement of the Waiaru block. The cover strata are of the late Miocene and late Quaternary. Samples 9414$19,-20,-21$ and -25 (Fig. 2), lying in the vicinity of the Alpine Fault bend, have very young FT ages ( $<10 \mathrm{Ma}$ ) of zircon (Table 2$)$, indicating that they have experienced the closure temperature of zircon $\left(-240^{\circ} \mathrm{C}\right)$. These FT ages can be correlated with recent rapid uplift/erosion in this area. Excluding these four samples, the zircon FT ages of thirteen samples (Table 2 and Fig. 3) in the Waiaru block are consistent with the depositional ages. The zircon FT ages (> $250 \mathrm{Ma}$ ) of the rest of the samples are older than the depositional ages, showing that they can be correlated with the source provenance. According to these FT data, the samples of the host rocks in this block have been slightly annealed and might have passed through the upper part of the zircon PAZ $\left(\sim 175^{\circ} \mathrm{C}\right)$ in the Mesozoic denudation.

\subsubsection{Inland Kaikoura transect (T2)}

Twelve samples of this transect were collected from the Inland Kaikoura Range which lies between the Awatere and Clarence Faults (Figs. 1 and 2). The stratigraphic units of the 
Table 1. Results of calibration of fission track age determinations by the zeta approach.

\begin{tabular}{|c|c|c|c|c|c|c|c|c|c|c|}
\hline \multirow{2}{*}{$\begin{array}{l}\text { Age Standard and } \\
\text { Irradiation No. }\end{array}$} & \multirow{2}{*}{$\begin{array}{l}\text { Mineral } \\
\text { (No. of crystals) }\end{array}$} & \multicolumn{2}{|c|}{ Spontaneous } & \multicolumn{2}{|c|}{ Induced } & \multirow{2}{*}{$\begin{array}{c}\mathrm{P}\left(\chi^{2}\right) \\
\%\end{array}$} & \multirow[t]{2}{*}{ Glass } & \multicolumn{2}{|c|}{ Dosimeter } & \multirow[t]{2}{*}{$\zeta \pm 1 \sigma$} \\
\hline & & $\rho_{s}$ & $\overline{\mathrm{N}}_{\mathrm{s}}$ & $\overline{\rho_{i}}$ & $\mathrm{~N}_{\mathrm{i}}$ & & & $\bar{\rho}$ & $\mathrm{N}_{d}$ & \\
\hline Buluk wk029 & Zircon (20) & 0.712 & 169 & 2.208 & 524 & 100 & CN1 & 0.8772 & 2169 & $114.7 \pm 10.5$ \\
\hline Buluk pt845 & Zircon (20) & 1.181 & 369 & 1.757 & 549 & 100 & U 3 & 0.4926 & 1218 & $98.0 \pm 7.3$ \\
\hline Tardree wk029 & Zircon (20) & 5.168 & 782 & 4.818 & 729 & 100 & CN1 & 0.8772 & 2193 & $123.9 \pm 7.3$ \\
\hline Tardree wk029 & Zircon (20) & 5.192 & 914 & 5.003 & 886 & 100 & CN1 & 0.8972 & 2218 & $127.4 \pm 70.0$ \\
\hline Tardree pt845 & Zircon (20) & 5.411 & 869 & 2.208 & 524 & 100 & CN1 & 0.8772 & 2169 & $114.7 \pm 10.5$ \\
\hline Mt Dromedary wk029 & Zircon (13) & 12.843 & 724 & 6.652 & 375 & 99 & CN1 & 0.9072 & 2240 & $113.6 \pm 7.6$ \\
\hline Mt Dromedary wk029 & Zircon (17) & 14.264 & 1058 & 8.170 & 606 & 100 & CN1 & 0.9172 & 2264 & $124.2 \pm 6.9$ \\
\hline Mt Dromedary pt845 & Zircon (10) & 11.994 & 949 & 2.958 & 234 & 100 & U3 & 0.4926 & 1218 & $99.6 \pm 7.8$ \\
\hline Mt Dromedary pt845 & Zircon (10) & 12.354 & 672 & 2.978 & 162 & 100 & U3 & 0.4926 & 1218 & $97.3 \pm 9.0$ \\
\hline Mt Dromedary pt846 & Zircon (15) & 13.891 & 1154 & 3.479 & 289 & 100 & U3 & 0.4930 & 1219 & $101.0 \pm 7.3$ \\
\hline Mt Dromedary pt846 & Zircon (15) & 14.720 & 1252 & 3.692 & 314 & 100 & U3 & 0.4930 & 1219 & $101.2 \pm 7.0$ \\
\hline Mt Dromedary pt846 & Zircon (20) & 12.464 & 1319 & 3.071 & 325 & 100 & U3 & 0.4930 & 1219 & $99.4 \pm 6.8$ \\
\hline Fish Canyon wk029 & Zircon (20) & 4.067 & 739 & 9.597 & 1739 & 99.7 & $\mathrm{CNI}$ & 0.9272 & 2291 & $141.8 \pm 5.4$ \\
\hline Fish Canyon pt845 & Zircon (20) & 4.112 & 1822 & 3.631 & 1609 & 32.4 & U3 & 0.4926 & 1218 & $99.9 \pm 5.1$ \\
\hline Fish Canyon pt845 & Zircon (20) & 5.023 & 2126 & 4.536 & 1920 & 100 & U3 & 0.4926 & 1218 & $102.2 \pm 5.1$ \\
\hline Fish Canyon pt846 & Zircon (13) & 4.135 & 773 & 3.713 & 649 & 100 & U3 & 0.4930 & 1219 & $101.5 \pm 6.6$ \\
\hline Mt Waming wk029 & Zircon (10) & 3.198 & 272 & 8.595 & 731 & 98.8 & CN1 & 0.9672 & 2387 & $126.9 \pm 9.8$ \\
\hline Mt Waming pt845 & Zircon (20) & 4.382 & 910 & 4.227 & 878 & 97.1 & U3 & 0.4926 & 1218 & $89.5 \pm 5.3$ \\
\hline Mt Warning pt845 & Zircon (13) & 5.009 & 426 & 4.327 & 368 & 97.1 & U3 & 0.4926 & 1218 & $80.1 \pm 6.4$ \\
\hline \multirow[t]{2}{*}{ Mt Warning pt846 } & Zircon (13) & 4.065 & 595 & 4.024 & 589 & 100 & U3 & 0.4930 & 1219 & $91.7 \pm 3.6$ \\
\hline & & & & & & & & \multicolumn{2}{|c|}{ Zircon Mean $\zeta$} & $140.2 \pm 3.6$ \\
\hline
\end{tabular}

Analyses of zircon age standards are by external detector method; track densities $(\rho)$ are $\left(x 106 \mathrm{~cm}^{-2}\right)$; $\mathrm{N}$ is number of tracks counted. $\mathrm{P}\left(\chi^{2}\right)$ is the probability of obtaining $\chi^{2}$ value for $v$ degrees of freedom where $\nu=\left(\right.$ Number of crystals-1) [Galbraith 1981]; pooled $\rho_{\mathrm{s}} / \rho_{\mathrm{j}}$ ratio used to calculate $\zeta$ and uncertainty where $\mathrm{P}\left(\chi^{2}\right)>5 \%$; mean $\rho_{s} / \rho_{\mathrm{i}}$ ratio used to calculate $\zeta$ and uncertainty where $\mathrm{P}\left(\chi^{2}\right)>5 \%$ [Green 1981]. Standard ages used are Fish Canyon Tuff 27.8 \pm 0.7 Ma, Tardree Rhyolite 58.7 $\pm 1.1 \mathrm{Ma}$ [Hurford and Green 1983]; Mount Dromedary Igneous Complex 98.7 $\pm 0.6 \mathrm{Ma}, \mathrm{Mount}$ Waming Complex $22.8 \pm 0.5 \mathrm{Ma}$ [Green 1985]; Buluk Member tuff 16.2 $\pm 0.2 \mathrm{Ma}$ [Hurford and Watkins 1987]. An uncertainty component from the independent age is included in the error on each $\zeta$ value; zircon mean $\zeta$ and its error weighted according to uncertainties on individual $\zeta$ values. Zircon $\zeta$ determinations fulfill the requirements proposed by Hurford [1990]. Zircon mean $\zeta$ calculated for CNI, with U3 sample determinations being converted to CN1 terms by using the factor of Green [1985]. 


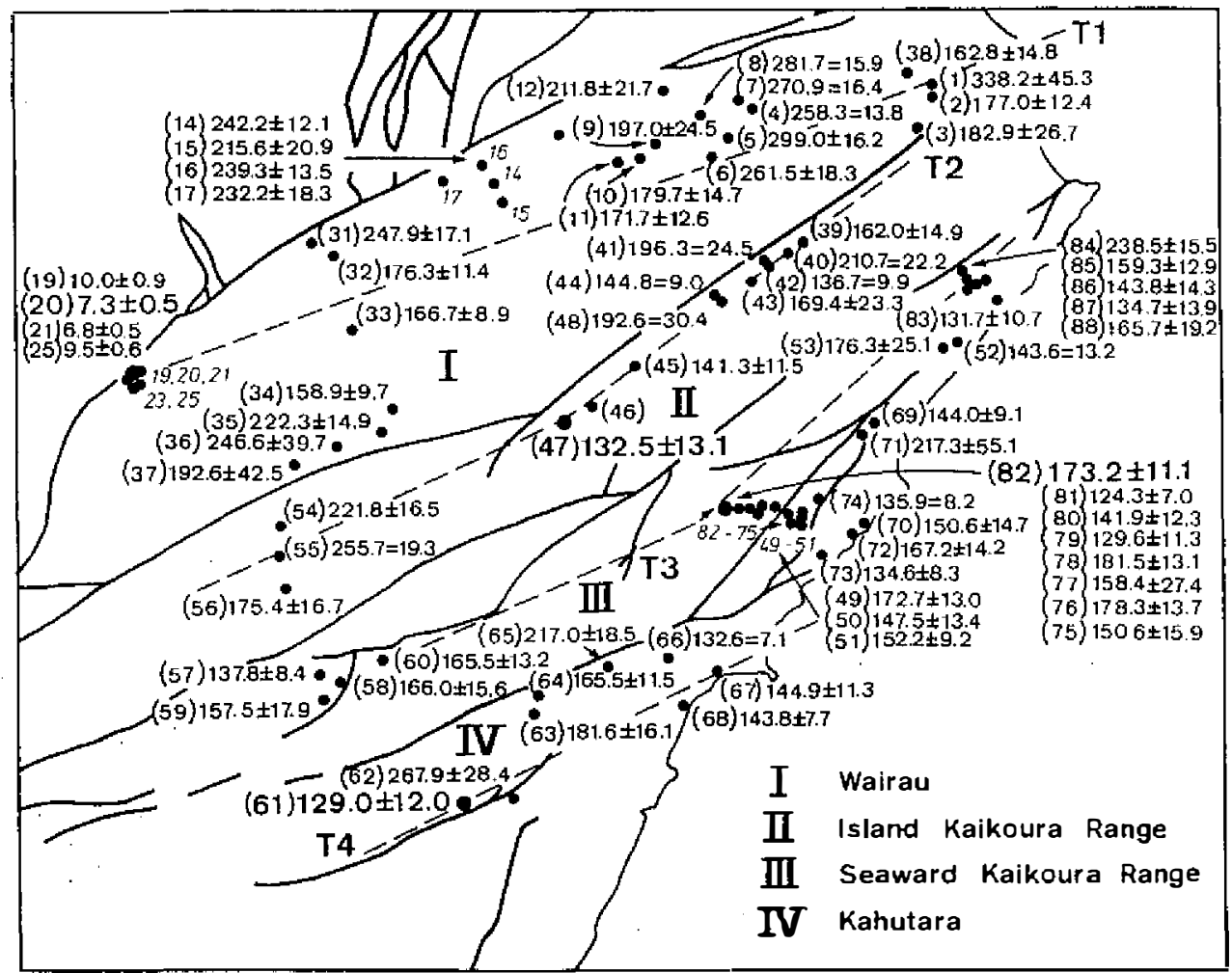

Fig. 2. Distribution of zircon fission track ages (given in Ma) in Marlborough. Four major blocks, designated I, II, III, and IV in the Marlborough region are shown. The main faults whose names are given in Fig. 1 are indicated by solid lines. Four transects (T1, T2, T3, and T4) shown in long-dashed lines are located within the four major blocks, respectively. The sample numbers with their prefix 9414- omitted are shown in parentheses.

basement in the Inland Kaikoura block are similar to those of the Wairau block. The depositional ages of cover strata range from Cretaceous to Quaternary. Most zircon FT ages of the samples are in accordance with the depositional ages (from Triassic to Jurassic) (Table 2 and Fig. 4), implying that the host rocks have not experienced the PAZ of zircon $\left(175^{\circ} \mathrm{C} \sim 245^{\circ} \mathrm{C}\right)$. In addition, most host rock samples in this block are low in $\mathrm{P}\left(\chi^{2}\right)$ values $(<5 \%)$ (Table 2$)$, showing that they might have experienced the upper part of the zircon PAZ $\left(\sim 175^{\circ} \mathrm{C}\right)$ during the Mesozoic denudation.

\subsubsection{Seaward Kaikoura transect (T3)}

The stratigraphic units of the basement in the Seaward Kaikoura block are the same as those of the Inland Kaikoura block (Fig. 1). Except Sample 9414-84, most zircon FT ages 
Table 2. Zircon fission track data for Marlborough samples.

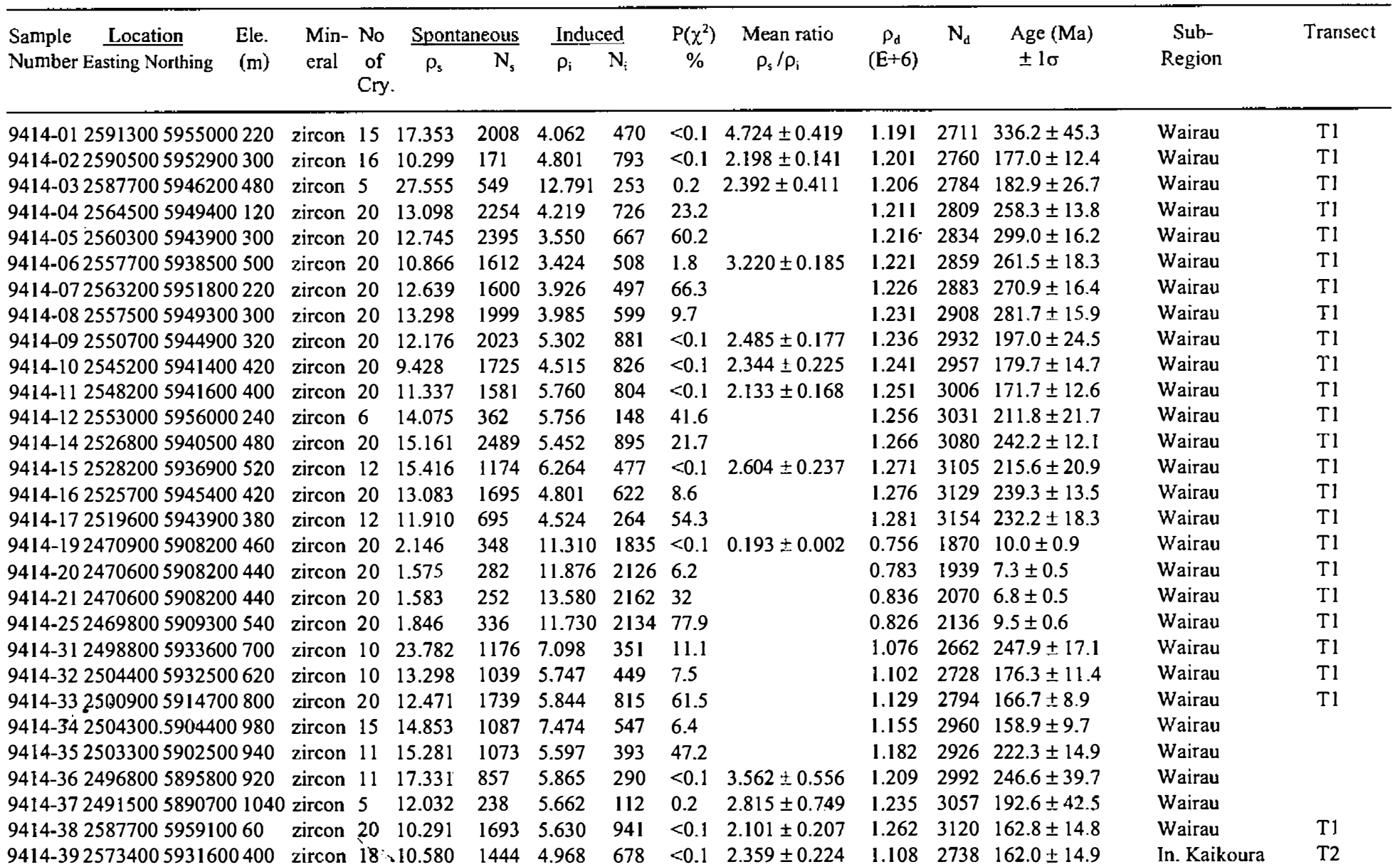


(Table 2. continued)

\begin{tabular}{|c|c|c|c|c|c|c|c|c|c|c|c|c|c|c|}
\hline \multirow{2}{*}{$\begin{array}{l}\text { Sample Location } \\
\text { Number Easting Northing }\end{array}$} & \multirow{2}{*}{$\begin{array}{l}\text { Ele. } \\
(\mathrm{m})\end{array}$} & \multirow{2}{*}{$\begin{array}{l}\text { Min- } \\
\text { eral }\end{array}$} & \multirow{2}{*}{$\begin{array}{l}\text { No } \\
\text { of } \\
\text { Cry. }\end{array}$} & \multicolumn{2}{|c|}{ Spontaneous } & \multicolumn{2}{|c|}{ Induced } & \multirow{2}{*}{$\begin{array}{c}P\left(\chi^{2}\right) \\
\%\end{array}$} & \multirow{2}{*}{$\begin{array}{c}\text { Mean ratio } \\
\rho_{\mathrm{s}} / \rho_{\mathrm{i}}\end{array}$} & \multirow{2}{*}{$\begin{array}{c}\rho_{\mathrm{d}} \\
(\mathrm{E}+6)\end{array}$} & \multirow[t]{2}{*}{$\mathrm{N}_{\mathrm{d}}$} & \multirow{2}{*}{$\begin{array}{l}\text { Age }(\mathrm{Ma}) \\
\pm \mathrm{l \sigma}\end{array}$} & \multirow{2}{*}{$\begin{array}{c}\text { Sub- } \\
\text { Region }\end{array}$} & \multirow[t]{2}{*}{ Transect } \\
\hline & & & & $\rho_{s}$ & $N_{s}$ & $\rho_{\mathrm{i}}$ & $N_{i}$ & & & & & & & \\
\hline $9414-40257080059298$ & 0400 & zircon & 6 & 9.645 & 372 & 3.526 & 136 & 20.1 & & 1.117 & 2761 & $210.7 \pm 22.2$ & In. Kaikoura & $\mathrm{T} 2$ \\
\hline $9414-412567600592770$ & 0400 & zircon & 10 & 10.900 & 636 & 4.182 & 244 & 0.3 & $2.746 \pm 0.296$ & 1.127 & 2785 & $196.3 \pm 24.5$ & In. Kaikoura & T2 \\
\hline $9414-422567700592760$ & 0400 & zircon & 20 & 8.558 & 1515 & 5.005 & 886 & $<0.1$ & $1.900 \pm 0.161$ & 1.136 & 2809 & $136.7 \pm 9.9$ & In. Kaikoura & $\mathrm{T} 2$ \\
\hline $9414-432564700592550$ & 0400 & zircon & $10 \varepsilon$ & 8.241 & 595 & 3.837 & 277 & $<0.1$ & $2.410 \pm 0.286$ & 1.146 & 2833 & $169.4 \pm 23.3$ & In. Kaikoura & $\mathrm{T} 2$ \\
\hline $9414-442558900592350$ & 0510 & zircon & 20 & 8.740 & 994 & 4.836 & 550 & 43.2 & & 1.156 & 2856 & $144.8 \pm 9.0$ & In. Kaikoura & $\mathrm{T} 2$ \\
\hline $9414-452544900591190$ & 01280 & zircon & 20 & 8.905 & 1418 & 5.024 & 800 & $<0.1$ & $1.904 \pm 0.183$ & 1.166 & 2880 & $141.3 \pm 11.5$ & In. Kaikoura & $\mathrm{T} 2$ \\
\hline $9414-472532300590330$ & 0900 & zircon & 20 & 11.698 & 995 & 7.160 & 609 & $<0.1$ & $1.715 \pm 0.202$ & 1.185 & 2927 & $132.5 \pm 13.1$ & In. Kaikoura & $\mathrm{T} 2$ \\
\hline $9414-482559100592350$ & 0500 & zircon & 12 & 10.066 & 667 & 4.376 & 290 & $<0.1$ & $2.101 \pm 0.207$ & 1.195 & 2951 & $192.6 \pm 30.4$ & In. Kaikoura & $\mathrm{T} 2$ \\
\hline $9414-492570200588680$ & 0620 & zircon & 20 & 8.426 & 75 & 5.370 & 887 & $<0.1$ & $2.343 \pm 0.229$ & 1.205 & 2974 & $172.7 \pm 13.0$ & Sea. Kaikoura & T3 \\
\hline $9414-502570300588630$ & 0640 & zircon & 20 & 10.203 & 1675 & 5.774 & 948 & $<0.1$ & $1.931 \pm 0.187$ & 1.215 & 2998 & $147.5 \pm 13.4$ & Sea. Kaikoura & T3 \\
\hline $9414-512570400588570$ & 0460 & zircon & 20 & 10.100 & 1738 & 5.645 & 973 & 0.3 & $1.891 \pm 0.125$ & 1.224 & 3022 & $152.2 \pm 9.2$ & Sea. Kaikoura & $\mathrm{T} 3$ \\
\hline $9414-5225918005914600$ & 070 & zircon & 7 & 6.320 & 361 & 5.176 & 215 & 55.6 & & 1.234 & 3046 & $143.6 \pm 13.2$ & Sea. Kaikoura & T3 \\
\hline $9414-53259160059150$ & 0120 & zircon & 10 & 8.999 & 712 & 4.386 & 347 & $<0.1$ & $2.450 \pm 0.443$ & 1.243 & 3070 & $176.3 \pm 25.1$ & Sea. Kaikoura & $\mathrm{T} 3$ \\
\hline $9414-542491200587950$ & 01040 & zircon & 16 & 13.104 & 1620 & 5.080 & 628 & 0.2 & $2.748 \pm 0.241$ & 1.253 & 3093 & $221.8 \pm 16.5$ & In. Kaikoura & $\mathrm{T} 2$ \\
\hline $9414-5524923005873100$ & 0900 & zircon & 13 & 11.096 & 1284 & 3.820 & 442 & 3.6 & $3.143 \pm 0.225$ & 1.263 & 3117 & $255.7 \pm 19.3$ & In. Kaikoura & $\mathrm{T} 2$ \\
\hline $9414-5624931005865100$ & 0840 & zircon & 10 & 8.922 & 803 & 4.578 & 412 & 0.7 & $2.177 \pm 0.231$ & 1.272 & 3141 & $175.4 \pm 16.7$ & In. Kaikoura & $\mathrm{T} 2$ \\
\hline $9414-5724982005861600$ & 0800 & zircon & 10 & 10.245 & 922 & 6.600 & 594 & 11.0 & & 1.280 & 3165 & $137.8 \pm 8.4$ & Sea. Kaikoura & T3 \\
\hline $9414-5825000005856400$ & 0700 & zircon & 16 & 8.243 & 1125 & 3.488 & 476 & $<0.1$ & \pm 0.256 & 1.050 & 2595 & $166.0 \pm 15.6$ & Sea. Kaikoura & T3 \\
\hline $9414-5925025005861100$ & 0760 & zircon & 18 & 6.962 & 1267 & 3.116 & 567 & $<0.1$ & $2.588 \pm 0.348$ & 1.054 & 2605 & $157.5 \pm 17.9$ & Sea. Kaikoura & T3 \\
\hline $9414-6025058005867300$ & 0780 & zircon & 16 & 11.177 & 1647 & 4.954 & 730 & $<0.1$ & $2.416 \pm 0.199$ & 1.058 & 2615 & $165.5 \pm 13.2$ & Kahutara & $\mathrm{T} 3$ \\
\hline $9414-61252020058395$ & 0110 & zircon & 20 & 10.384 & 1941 & 5.692 & 1064 & $<0.1$ & $1.960 \pm 0.207$ & $1: 062$ & 2624 & $129.0 \pm 12.0$ & Kahutara & T4 \\
\hline $9414-622527900584000$ & 0140 & zircon & 10 & 13.016 & 1210 & 3.399 & 316 & 0.2 & $3.933 \pm 0.512$ & 1.066 & 2634 & $267.9 \pm 28.4$ & Kahutara & $\mathrm{T} 4$ \\
\hline $9414-6325324005860500$ & 0360 & zircon & 20 & 9.786 & 1684 & 3.789 & 652 & $<0.1$ & $2.700 \pm 0.252$ & 1.070 & 2644 & $181.6 \pm 16.1$ & Kahutara & T4 \\
\hline $9414-6425031005863000$ & 0400 & zircon & 20 & 8.572 & 1526 & 3.910 & 696 & 0.3 & $2.423 \pm 0.175$ & 1.073 & 2654 & $165.5 \pm 11.5$ & Kahutara & $\mathrm{T} 4$ \\
\hline $9414-6525436005868300$ & 0280 & zircon & 20 & 11.463 & 2120 & 4.099 & 758 & $<0.1$ & $3.065 \pm 0.262$ & 1.077 & 2664 & $217.0 \pm 18.5$ & Kahutara & $\mathrm{T} 4$ \\
\hline $9414-6625517005867700$ & 0100 & zircon & 20 & 8.245 & 1476 & 4.665 & 835 & 54.4 & & 1.081 & 2674 & $132.6 \pm 7.1$ & Kahutara & $\mathrm{T} 4$ \\
\hline $9414-6725584005863300$ & 020 & zircon & 20 & 11.603 & 2100 & 5.951 & 1077 & $<0.1$ & $2.100 \pm 1.910$ & 1.085 & 2683 & $144.9 \pm 11.3$ & Kahutara & $\mathrm{T} 4$ \\
\hline $9414-6825534005858000$ & 020 & zircon & 15 & 12.329 & 1573 & 6.474 & 826 & 14.8 & & 1.089 & 2693 & $143.8 \pm 7.7$ & Kahutara & $\mathrm{T} 4$ \\
\hline $9414-6925785005902200$ & 0150 & zircon & 20 & 11.022 & 1875 & 5.743 & 977 & $<0.1$ & $1.991 \pm 0.148$ & 1.093 & 2703 & $144.0 \pm 9.1$ & Kahutara & T3 \\
\hline
\end{tabular}


(Table 2. continued)

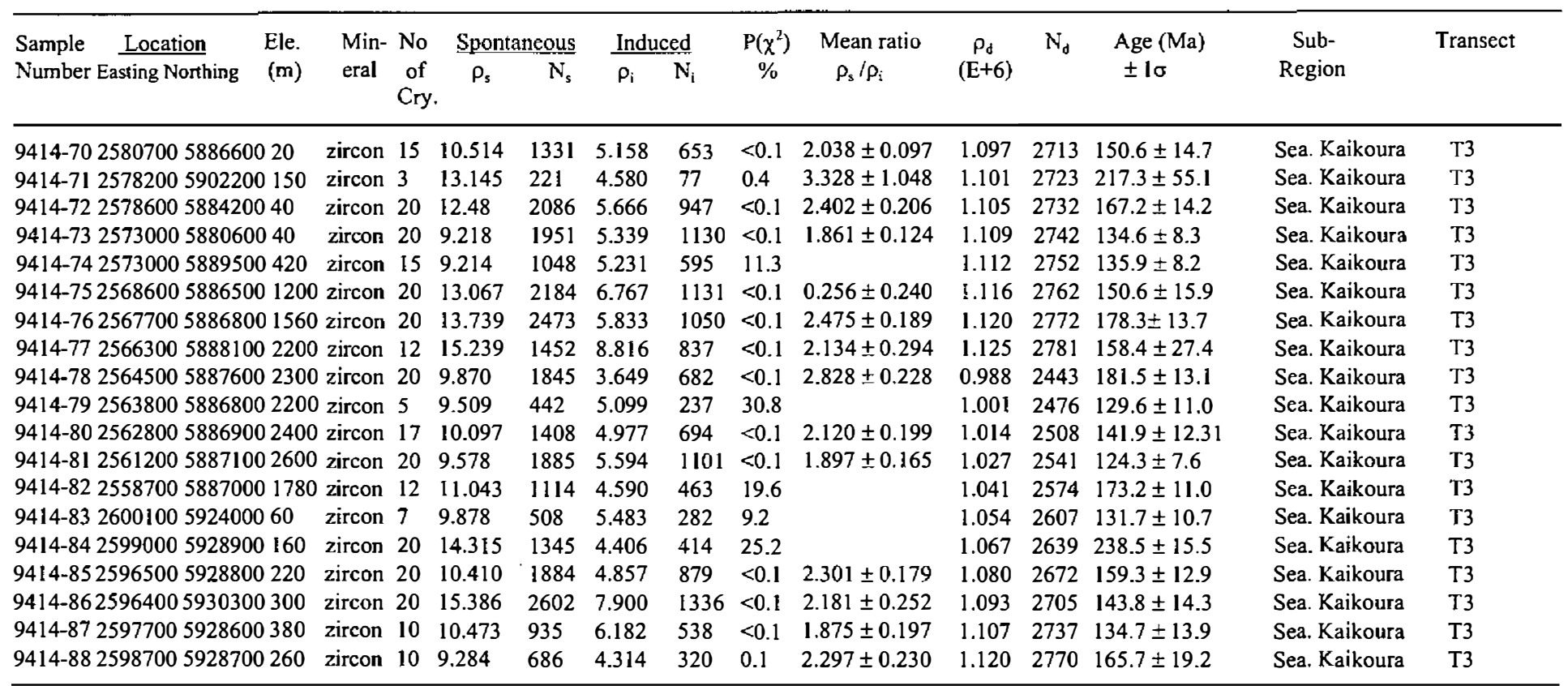

Easting and northing refer to New Zealand Map Series 260 . Track densities $(\rho)$ are $\times 10^{6}$ tracks $\mathrm{cm}^{-2}$. All analyses are by external detector method using 0.5 for the $4 \pi / 2 \pi$ geometry correction factor. Zircon ages calculated using dosimeter glass $\mathrm{CN} 1$ and zeta-CNl $=1402 \pm 3.6(1 \sigma)$. $\mathrm{P}\left(\chi^{2}\right)$ is probability of obtaining $\chi^{2}$ value for $v$ degrees of freedom (where $v$ is number of crystals -1 ) [Galbraith 1981]; pooled $\rho_{s} / \rho_{i}$ ration is used to calculate age and uncertainty where $\mathrm{P}\left(\chi^{2}\right)>5 \%$; mean $\rho_{s} \rho_{\mathrm{i}}$ ration is used to calculate age and uncertainty where $\mathrm{P}\left(\chi^{2}\right)<5 \%$ [Green 1981]. Ele.: elevation (m); Cry.: crystals; In.: Inland; Sea.: Seaward. 


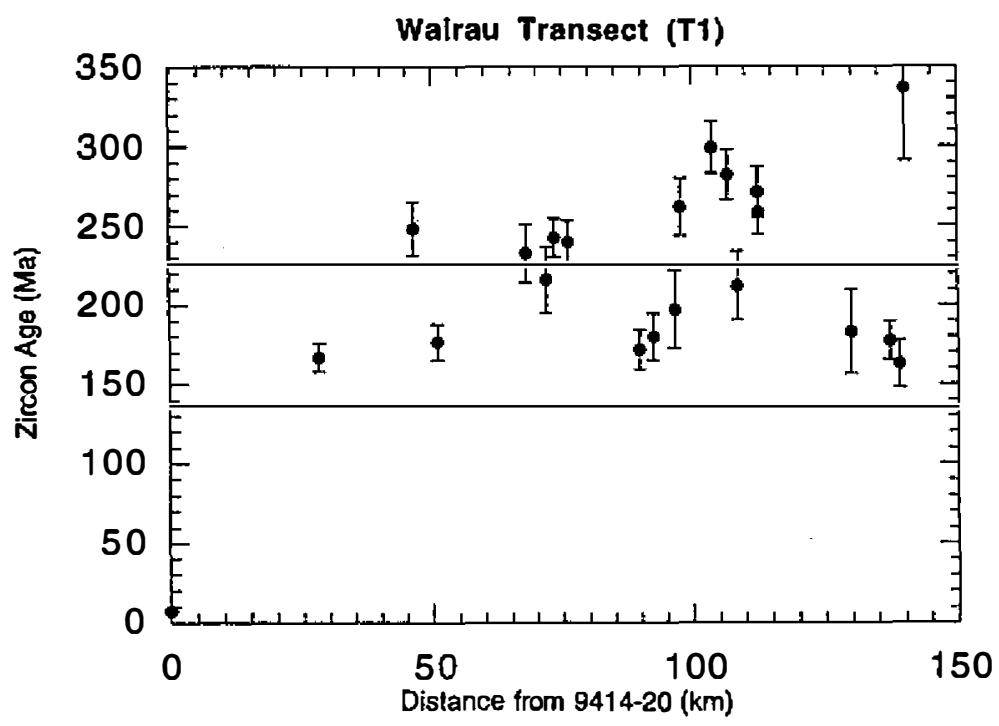

Fig. 3. Zircon fission track ages versus distance from Sample 9414-20 along Transect T1. The area between two horizontal lines is the depositional age (from Triassic to Jurassic). Samples 9414-34, -35, -36, and -37 are excluded.

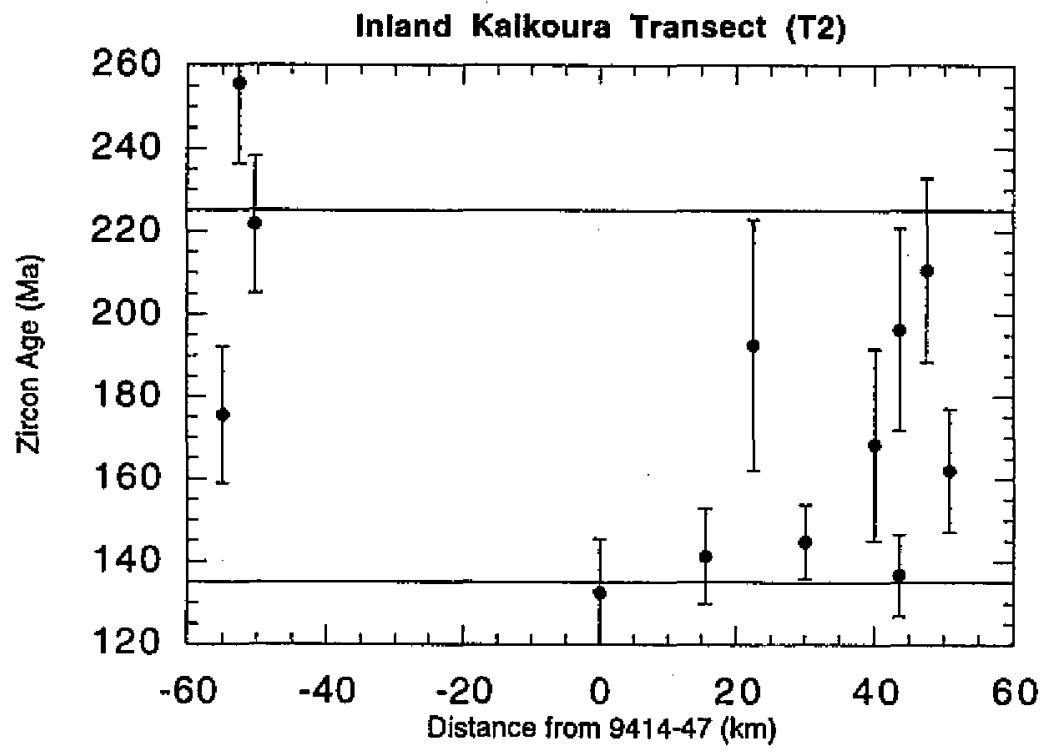

Fig. 4. Zircon fission track ages versus distance from Sample 9414-47 along Transect T2; the area between two horizontal lines is the depositional age (from Triassic to Jurassic). The distance is arbitrarily designated as positive for the samples northeast from Sample 9414-47, and as negative for the samples southwest from Sample 9414-47. 


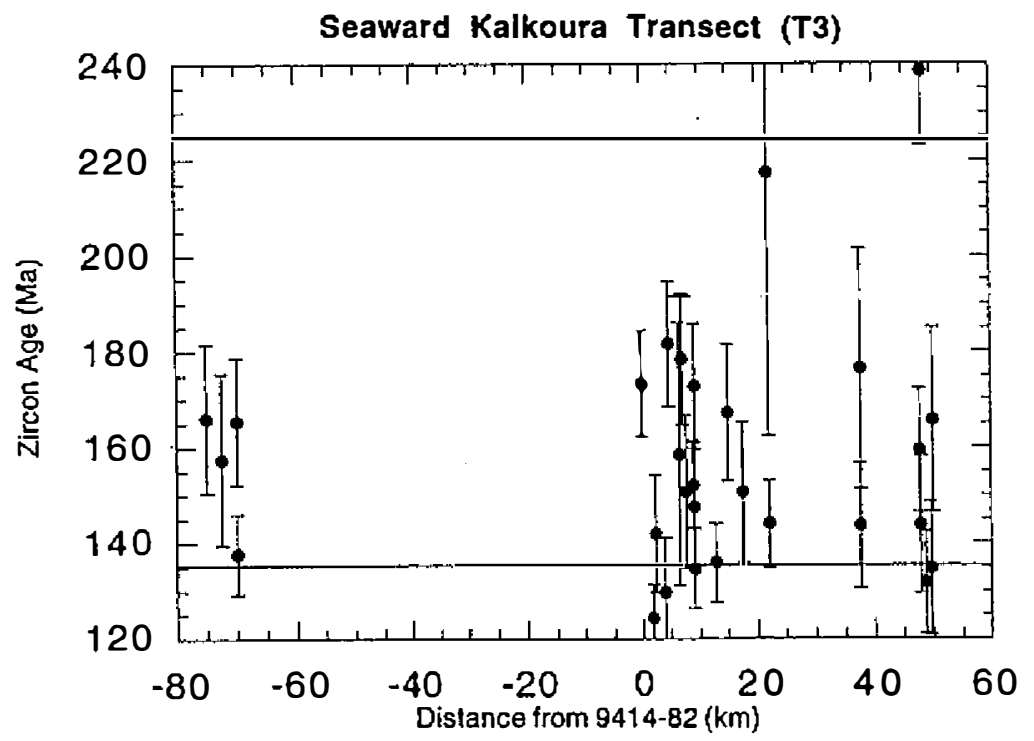

Fig. 5. Zircon fission track ages versus distance from Sample 9414-82 along Transect T3; the area between two horizontal lines is the depositional age (from Triassic to Jurassic). The distance is arbitrarily designated as positive for the samples northeast from Sample 9414-82, and as negative for the samples southwest from Sample 9414-82.

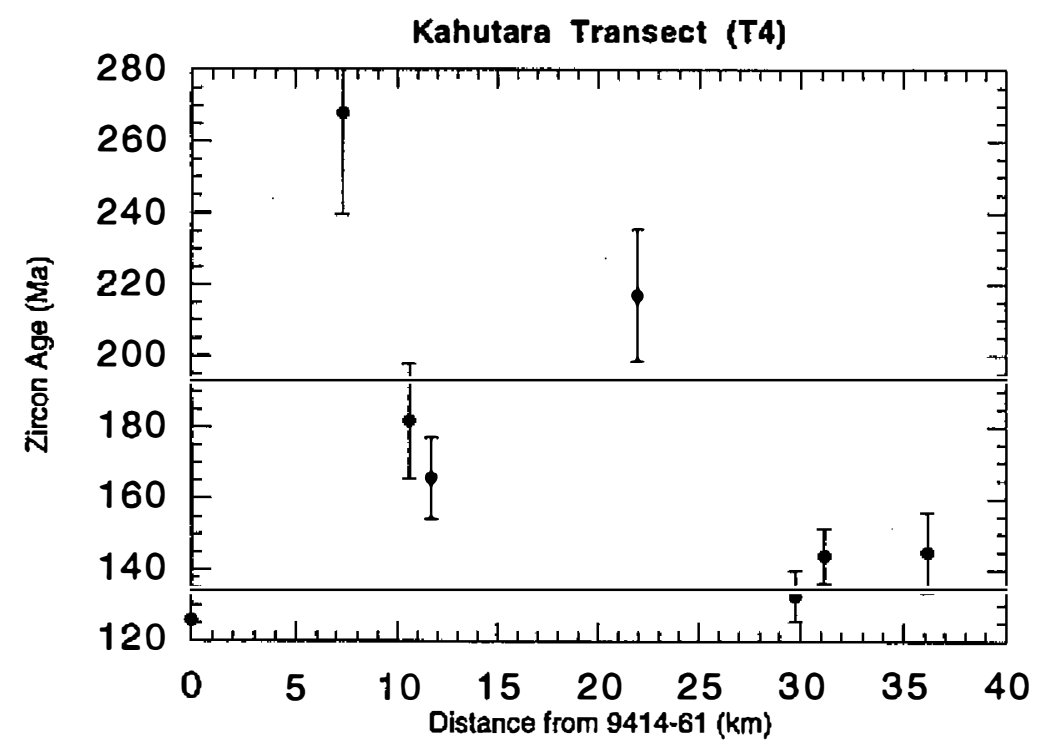

Fig. 6. Zircon fission track ages versus distance from Sample 9414-61 along Transect T4; the area between two horizontal lines is the depositional age (Jurassic). 
(Table 2 and Fig. 5) are consistent with the depositional ages (from Triassic to Jurassic), reflecting that the host rocks have not passed through the PAZ of zircon. Samples 9414-79 and 81 with young zircon FT ages ( 124-129 Ma) indicate that they have been annealed. Similar to those of the Inland Kaikoura transect, most host rock samples are low in $\mathrm{P}\left(\chi^{2}\right)$ values $(<5 \%)$, reflecting that they might have also passed through the upper part of the zircon PAZ $\left(\sim 175^{\circ} \mathrm{C}\right)$ during the Mesozoic cooling.

\subsubsection{Kahutara transect (T4)}

Eight samples (9414-61 to -68) were collected from south of the Hope Fault (Figs. 1 and 2), and belong to Jurassic depositional ages. Sample 9414-61 with a young zircon FT age ( $129 \mathrm{Ma}$ ) (Table 2 and Fig. 6) indicates that it experienced the PAZ of zircon. Except for Samples 9414-62 and -65, the zircon FT ages of the samples (Table 2 and Fig. 6) in the Kahutara block are consistent with the depositional age, reflecting that the host rocks have not passed through the PAZ of zircon. In brief, the samples in this block might be slightly annealed. The older zircon FT ages ( $>200 \mathrm{Ma}$ ) (Samples $9414-62$ and -65 ) may be related to the source provenance of the sediments.

\subsection{Apatite Results}

Modeled thermal histories (Fig. 7) of apatite samples with good length data were reported in the paper of Kao (2001). The modeled thermal histories indicate two major cooling events: the earlier one occurring in the mid-Cretaceous ( 100 Ma) and the later one lasting from the early Miocene ( $20 \mathrm{Ma})$ to the present. Annealed apatite FT data show that the host rocks experienced the PAZ of apatite. The timing of the main Neogene uplift/erosion event was earlier (mid to late Miocene) in the Wairau block than that in the place to the southeast of the Seaward Kaikoura Range (late Pliocene-Pleistocene). The modeled thermal histories of the samples collected from Kaikoura Ranges reflect the continuance of the cooling event from Pliocene to the present. In addition, the samples in the north Marlborough rather than those in the south experienced partial annealing in the lower part of the apatite PAZ.

\subsection{Interpretation}

Significant thermo-tectonic implications can be discussed in the light of the apatite and zircon FT data presented above.

The extremely young zircon ages ( 6.8-10.0 Ma) of the samples $(9414-19,-20,-21$ and 25) lying in the vicinity of the Alpine Fault bend reveal that the FTs have been reset during the recent rapid uplift and experienced cooling from temperatures of $\sim 240^{\circ} \mathrm{C}$, the closure temperature of zircon. Except for these reset samples, most of the zircon ages are consistent with the stratigraphic ages. In addition, there are three samples (9414-61, -79 and -81) with zircon ages (124-129 Ma) younger than the stratigraphic ages, showing that the samples have been slightly annealed. The host rocks passed through the upper part of the partial annealing zone of zircon $\left(\sim 175^{\circ} \mathrm{C}\right)$ during the Mesozoic denudation.

The results of apatite and zircon FT data (Figs. 3-7) can model thermal histories of the 


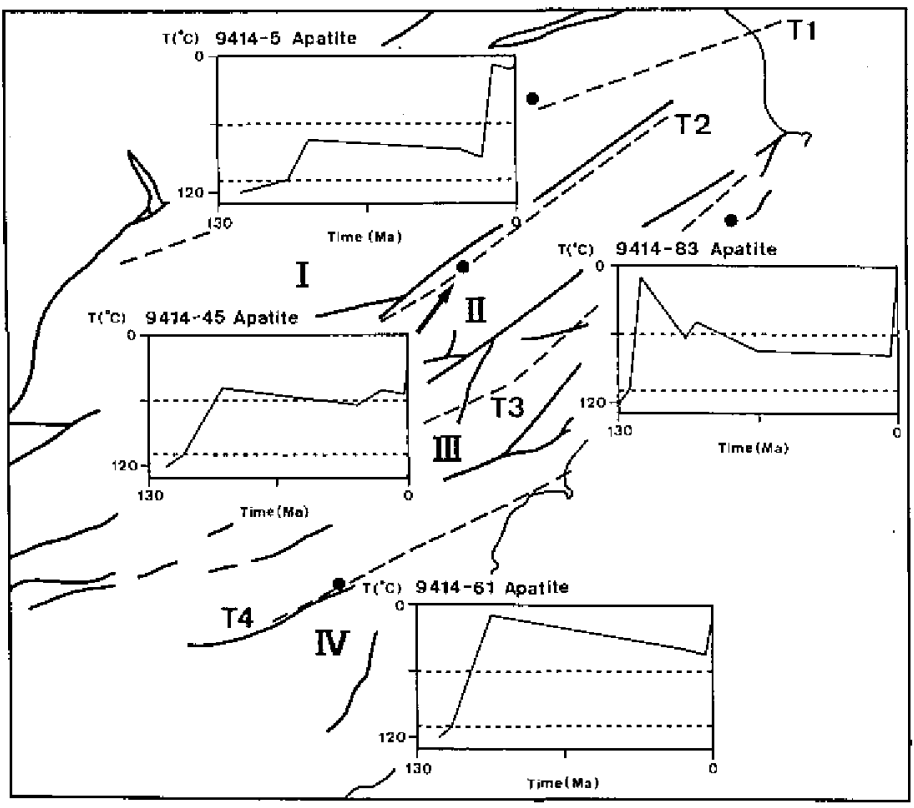

Fig. 7. Modeled thermal histories of Marlborough, established by the apatite fission track data (modified from Kao 2001). The area between two short-dashed lines is the apatite partial annealing zone (PAZ).

four blocks in Marlborough as shown in Fig. 8. Thermal histories in different blocks show different patterns of temperature-time paths, implying that each block has experienced its own thermo-tectonic history. Except those in the vicinity of the Alpine Fault bend, most of the host rocks in Marlborough have not experienced exposure to the closure temperature of zircon in the Mesozoic burial, but passed through the partial annealing zone (PAZ) of apatite.

\subsection{Correlation with Other Geologic Events}

Apatite and Zircon FT data show that there were two major cooling events, the earlier one occurring in the mid-Cretaceous $(\sim 100 \mathrm{Ma})$ and the later one expanding from the early Miocene ( $20 \mathrm{Ma})$ to the present.

The earlier cooling event can be correlated with a magmatic and extension event that occurred around $\sim 100 \mathrm{Ma}$ in this region, as supported by the following evidence: (a) the $\mathrm{Rb}-\mathrm{Sr}$ and FT ages of an igneous pluton, forming the peaks of the Inland Kaikoura Range, range from 105 to 93 Ma (Baker and Seward 1996), (b) one formation (105-100 Ma) unconformably overlies Torlesse basement (Reay 1993), and (c) terrestrial sediments (94-100 Ma) overlies a marine fan delta sequence, showing an end of a regress event (Reay 1993). The later cooling event ( $20 \mathrm{Ma})$ can be correlated with the sedimentation of the Great Marlborough Conglomerate (Browne 1995) which indicates rapid uplift and erosion during the early Miocene ( 20 Ma). Thrusting and shortening deformation became dominant during the late Cenozoic Kaikoura Orogeny. The initial movements of the Marlborough Fault System can be related to the Great Marlborough Conglomerate (Browne 1995).

Apatite and Zircon FT ages ( $<10 \mathrm{Ma}$ ) of the host rocks in the vicinity of the Alpine Fault bend coincide with the recent rapid uplift/erosion, related to the continuation of Kaikoura 


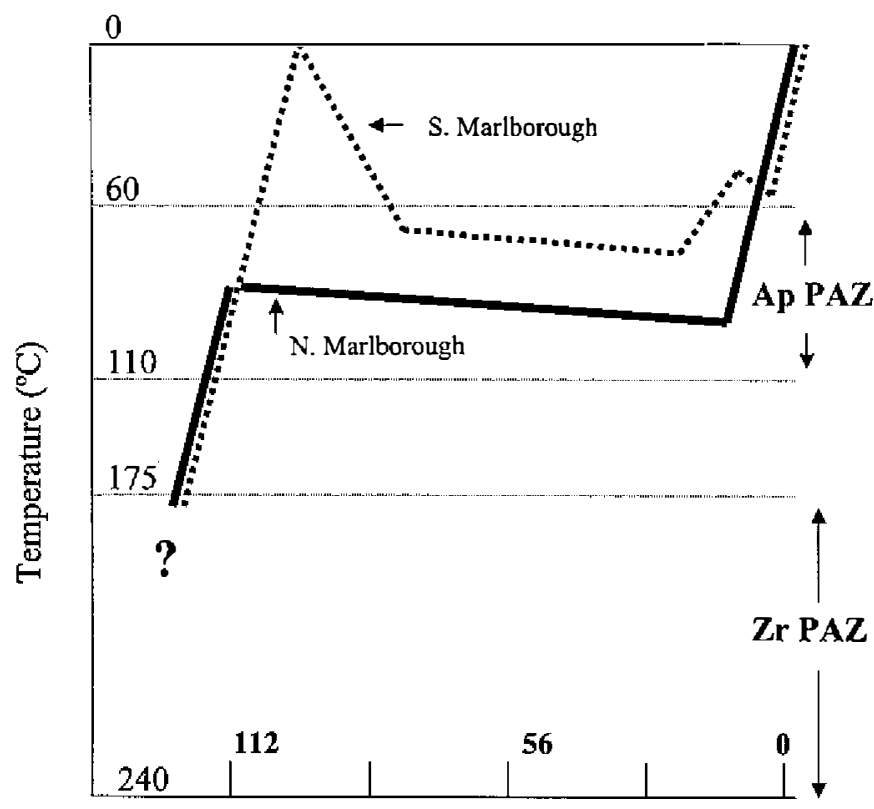

Fission Track Age (Ma)

Fig. 8. Modeled thermal histories of the Marlborough region, assessed by zircon and apatite fission rack data in the present study. The solid and dotted lines indicate the modeled thermal histories of the northern and southern parts of the Marlborough region, respectively. Ap: apatite; Zr: zircon; PAZ: partial annealing zone.

Orogeny. The temperature-time path in the Marlborough region modeled by zircon and apatite FT data (Fig. 8) shows the thermo-tectonic characters of two major cooling events in the present region.

\section{CONCLUSIONS}

The young ages ( $<10 \mathrm{Ma})$ of zircon in the vicinity of the Alpine Fault bend can be correlated with the recent rapid uplift/erosion in this area. Most of the zircon FT ages are consistent with depositional ages. Three samples, collected from the SE Marlborough (Seaward Kaikoura Range and Kahutara areas), have younger zircon ages (< depositional ages), indicating that the host rocks in SE Marlborough have experienced exposure to the temperatures close to the upper zone of partial annealing for zircon $\left(\sim 175^{\circ} \mathrm{C}\right)$ and cooled in the late Mesozoic denudation. In addition, the zircon and apatite FT data show that the host rocks in Marlborough have not experienced exposure to the PAZ of zircon in the Mesozoic burial, but passed through the PAZ of apatite. Each of the four blocks in Marlborough has experienced different temperature-time paths since the late Mesozoic cooling. The host rocks in the north rather than those in the south passed through the lower part of apatite PAZ. 
Acknowledgements The author would like to express thanks to Professor Peter Kamp of The University of Waikato for his guidance and support. The experimental work was completed at the Fission Track Laboratory of the Earth Sciences Department, University of Waikato, New Zealand. The author is also grateful to Frank Bailey for his kindness and encouragement. Thanks are due to Research Fellows, H.C. Chiu and T.F. Yui, the Institute of Earth Sciences, Academia Sinica, for their enthusiastic help and encouragement. In addition, the author appreciates three anonymous reviewers for their suggestions and comments. This manuscript was written up whilst the author was a postdoctoral fellow at the Institute of Earth Sciences, Academia Sinica, Taipei, Taiwan during 2001.

\section{REFERENCES}

Baker, J., and D. Seward, 1996: Timing of Cretaceous extension and Miocene compression in northeast South Island, New Zealand: Constraints from Rb-Sr and fission-track dating of an igneous pluton. Tectonics, 15, 976-983.

Browne, G. H., 1995: Sedimentation patterns during the Neogene in Marlborough, New Zealand. J. Roy. Soc. New Zealand, 4, 459-483.

Carter, R. M., and R. J. Norris, 1976: Cainozoic history of Southern New Zealand: An accord between geological observations and plate tectonic predictions. Earth and Planet. Sci. Lett., 31, 85-94.

Crowley, K. D., M. Cameron, and R. L. Schaeffer, 1991: Experimental studies of annealing of etched fission tracks in fluorapatite. Geochimica et Cosmochimica Acta, 55, 14491465.

Dodson, M. H., 1973: Closure temperature in cooling geochronological and petrological systems. Contrib. Mineral. Petrol., 40, 259-274.

Duddy, I. R., P. F. Green, and G. M. Laslett, 1988: Thermal annealing of fission tracks in apatite 3. Variable temperature behaviour. Chem. Geol. (Isot. Geosci. Sect.), 73, 25-38.

Galbraith, R. F., 1981: On statistical modeIs for fission track counts. Mathematical Geology, 13, 471-478.

Gleadow, A. J. W., 1981: Fission track dating methods: What are the real alternatives? Nucl. Tracks, 5, 3-14.

Gleadow, A. J. W., and I. R. Duddy, 1981: A natural long-term track annealing experiment for apatite. Nucl. Tracks, 5, 169-174.

Green, P. F., 1981: A new look at statistics in fission track dating. Nucl. Tracks, 5, 77-86.

Green, P. F., 1985: Comparison of zeta calibration baselines for fission track dating of apatite, zircon and sphene. Chem. Geol., 58, 1-22.

Green, P. F., 1986: On the thermo-tectonic evolution of Northern England: Evidence from fission track analysis. Geol. Mag., 123, 493-506.

Green, P. F., I. R. Duddy, G. M. Laslett, K. A. Hegarty, A. J. W. Gleadow, and J. F. Lovering, 1989a: Thermal annealing of fission tracks in apatites 4. Quantitative modelling techniques and extension to geological time scales. Chem. Geol. (Isot. Geosci. Sect.), 79, 155-182. 
Green, P. F., I. R. Duddy, A. J. W. Gleadow, and J. F. Lovering, 1989b: Apatite fission track analysis as a paleotemperature indicator for hydrocarbon exploration, in Thermal history of sedimentary basins. In: N. D. Naeser, and T. H. McCulloch (Eds.), SpringerVerlag, New York.

Hodges, K. V., 1991: Pressure-Temperature-Time Paths. Annual Reviews of Earth and Planet. Sci. Lett., 19, 207-236.

Hurford, A. J., 1990: International union of geological sciences subcommission on geochronology: Recommendation for the standardization of fission track dating calibration and data reporting. Nucl. Tracks, 17, 233-236.

Hurford, A. J., and P. F. Green, 1982: A users' guide to fission track dating calibration, Earth and Planet. Sci. Lett., 59, 343-354.

Hurford, A. J., and P. F. Green, 1983: The zeta age calibration of fission track dating. Isot. Geosci, 1, 285-317.

Hurford, A, J., and R. T. Watkins, 1987: Fission track age of the tuffs of the Buluk Member, Bakate Formation, northern Kenya: A suitable fission track age standard. Chem. Geol., 66, 209-216.

Kamp, P. J. J., P. F. Green, and S. H. White. 1989: Fission track analysis reveals character of collisional tectonics in New Zealand. Tectonics, 8, 169-195.

Kao, M.-H., 1998: Tectonic Evolution of the Marlborough Region, South Island, New Zealand, (Unpublished) Ph.D., University of Waikato, New Zealand.

Kao, M.-H., 2001: Thermo-tectonic history of the Marlborough Region, South Island, New Zealand. TAO, 12, 31-50.

Laslett, G. M., P. F. Green, I. R. Duddy, and A. J. W. Gleadow, 1987: Thermal annealing of fission tracks in apatite, 2. A quantitative analysis. Chem. Geol. (lsot. Geosci. Sect.), 65, $1-13$.

Lensen, G. J., 1962: Sheet 16, Kaikoura (1st Edn). Geological Map of New Zealand 1:250, 000, Department of Scientific and Industrial Research, Wellington, New Zealand.

Naeser, C. W., 1979: Thermal history of sedimentary basins in fission track dating of subsurface rocks. Spec. Publ. Soc. econ. Paleont. Miner., 26, 109-112.

Reay, M. B., 1993: Geology of the Middle Clarence Valley, Institute of Geological and Nuclear Sciences geological map 10, 1 sheet +144 , Institute of Geological and Nuclear Sciences Ltd., Lower Hutt, New Zealand.

Rohrman, M., P. van der Beek, P. nas Andriessen, 1994. Syn-rift thermal structure and postrift evolution of the Oslo rift (southeast Norway): New Constraints from fission track thermochronology. Earth and Plane. Sci. Lett., 127, 39-54.

Suggate, R. P., 1978a: The Kaikoura Orogeny. In: Suggate, R. P., Stevens, G. R., Te Punga, M. T. (Eds.), 672-673, Chapter 10, The geology of New Zealand.

Suggate, R. P., 1978b: The Kaikoura Orogeny. In: Suggate, R. P., Stevens, G. R., Te Punga, M. T. (Eds.), 680-682, Chapter 10, The geology of New Zealand.

Tippett, J. M., and P. J. J. Kamp, 1993: Fission Track Analysis of the Late Cenozoic Vertical Kinematics of Continental Pacific Crust, South Island, New Zealand. J. Geophys. Res., 98, 16119-16148. 